\title{
Sağlık Bilimleri Fakültesi Öğrencilerinin Toplumsal Cinsiyet Eşitliği Tutumlarının İncelenmesi
}

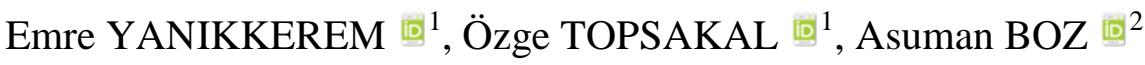

ÖZ

Amaç: Bu çalışmada üniversite öğrencilerinin toplumsal cinsiyet eşitliği tutumlarının incelenmesi amaçlanmıştır.

Gereç ve Yöntemler: Kesitsel tipte olan bu araştırma 2017-2018 güz yarıyılında Manisa Celal Bayar Üniversitesi Sağlık Bilimleri Fakültesi'nde eğitim görmekte olan 731 öğrenci ile gerçekleştirilmiştir. Araştırma verilerinin toplanmasında öğrencilerin tanıtıcı özellikleri soru formu ve "Toplumsal Cinsiyet Eşitliği Ölçeği” kullanılmıştır. Bu ölçek "Erkeği Üstün Gören Anlayış" ile "Kadını Erkeğe Bağımlı Kılan Anlayış" olmak üzere iki alt boyuttan oluşmaktadır. Verilerin analizinde Mann-Whitney U, Kruskal-Wallis ve Bonferroni düzeltmeli Mann-Whitney U testi kullanılmıștır.

Bulgular: Öğrencilerin \%73,3’ü kadın, \%29,7'si hemşirelik bölümünde okumakta, \%29,1'i birinci sınıf öğrencisi olup

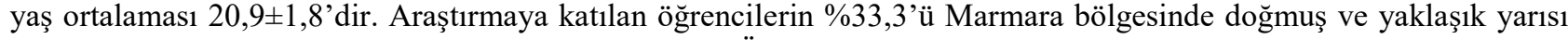
(\%51) en uzun süre ilde yaşadığını belirtmiştir. Erkeği Üstün Gören Anlayış puan ortancası ve Kadını Erkeğe Bağımlı Kılan Anlayış puan ortancası kadın, sosyal hizmet bölümünde okuyan, Marmara bölgesinde doğan, ebeveynin eğitim seviyesi yüksek ve ailesinin yanında ikamet eden öğrencilerde istatistiksel olarak düşüktür. Köyde yaşayan, toplumsal cinsiyet kavramını duymayan ve bu konuda eğitime katılmayan ya da toplumsal cinsiyet dersi almayan öğrencilerde Erkeği Üstün Gören Anlayış ve Kadını Erkeğe Bağımlı Kılan Anlayış puan ortancası istatistiksel olarak yüksek bulunmuștur.

Sonuç: $\mathrm{Bu}$ çalışmada toplumun gelişmesine öncülük edecek olan üniversite öğrencilerinin toplumsal cinsiyet eşitliğini sağlayacak yönde planlanan eğitim ve uygulamalara gereksinim olduğu belirlenmiş̧ir.

Anahtar Kelimeler: Cinsiyet; tutum; öğrenciler.

\section{Determination of the Attitudes of University Students at Faculty of Health Science about Gender Equality}

\begin{abstract}
Aim: The aim of the study was to determine the attitudes of university students about gender equality.

Material and Methods: The study was performed as cross sectional type with 731 students who educated at Faculty of Health Science, Manisa Celal Bayar University in 2017-2018 autumn semester. The student's characteristics form and "Gender Equality Scale” were used for data collection. The scale contains two subscales "Understanding that Considers Male as Superior" and "Understanding that Subjects Females to Males”. Mann-Whitney U-test, Kruskal-Wallis, and Mann-Whitney U test with Bonferroni correction were used to evaluate for data.

Results: Of the students $73.3 \%$ were women, 29.7\% were from nursing department, 29.1\% were first year students and the average age of them was $20.9 \pm 1.8$. 33.3\% of the participants were born in the Marmara region and approximately half (51\%) stated that they lived in the province for the longest time. The median score of the understanding that subjects females to males and understanding that considers male as superior were statistically lower female students, educated at social work, were born in the Marmara region, had parents who had higher education and accommodated with family. The median score of understanding that considers male as superior and understanding that subjects females to males was found to be statistically higher in the students who lived in rural areas, had not heard concept of social gender, and take course or lesson of social gender equality.
\end{abstract}

1 Manisa Celal Bayar Üniversitesi, Sağlık Bilimleri Fakültesi, Hemşirelik Bölümü, Doğum ve Kadın Hastalıkları Hemşireliği AD, Manisa, Türkiye 2 Üsküdar Üniversitesi, Sosyal Bilimler Enstitüsü, İstanbul, Türkiye 
Conclusion: In this study, it was determined that university students, who will lead the development of society, need training and practices planned in a way to ensure gender equality.

Keywords: Gender; attitude; students.

\section{GíRiș}

Cinsiyet kavramı, kişinin kadın ya da erkek olarak gösterdiği genetik, fizyolojik ve biyolojik özelliklerini tanımlarken (1); toplumsal cinsiyet kavramı toplumun kişilere verdiği rol, görev ve sorumlulukları, bireyin toplum tarafından nasıl görüldüğünü, algılandığını ve toplumun bireylerden beklentilerini içermektedir (2-5). Toplumsal cinsiyet dinamik bir kavram olup biyolojik cinsiyetin tersine içinde yaşanılan kültür tarafından etkilenmekte ve kültürden kültüre değişkenlik gösterebilmektedir (6-8).

Toplumsal cinsiyet rolleri toplumsal cinsiyet kavramının boyutlarından biri olup geleneksel olarak her iki cinsiyetten beklenen özellikler ve davranışları içermektedir (6). Erkek ve kadının rolleri geleneksel ve eşitlikçi roller olarak ele alınmaktadır. Geleneksel roller kadına ev işlerinden sorumlu olma, iş hayatında aktif olarak yer almama ve eşitlikçi olmayan sorumlulukları yüklerken erkeklere evin geçiminden sorumlu olma, evin reisi olma gibi görevler yüklemektedir. Buna rağmen eşitlikçi rollerde aile, evlilik, mesleki, eğitim ve sosyal yaşamda kadın ve erkeğin sorumlulukları eşit olarak paylaşmaları söz konusudur (9-11). Toplumsal yaşamın birçok alanında kadına ve erkeğe yüklenen bu roller, ayrımcılığa sebep olarak erkeğe kadından daha fazla değer verilmesine ve toplumda kadınların ikinci plana atılmalarına ve iki cinsiyet arasında eşitsizliğe neden olmaktadır. $\mathrm{Bu}$ eşitsizliğe özellikle kararlara katılım, seçme özgürlüğü, sağlık hizmetlerinden faydalanma, çalışma/fırsat eşitliği, eşit işe eşit ücret, eğitim ve meslek seçiminde daha fazla rastlanmaktadır $(3,10,12,13)$. Çalışma, aile yaşamı ve toplumsal yaşam alanlarına ilişkin yaşanılan bu ayrımcılık ise, kadınların toplumsal statüsünü olumsuz yönde etkilemekte ve kadını incinebilir duruma getirmektedir $(3,9,14)$.

Sosyal yaşamda kadın ve erkekler arasında eşitliğin sağlanarak kadının toplumsal statüsünün yükseltilmesi için toplumsal cinsiyet rollerine ilişkin toplumun farkındalığının arttırılması ve topluma duyarlılık kazandırılması önem taşımaktadır. Bu sebeple toplumsal cinsiyet rollerine ilişkin toplumundaki tüm bireylerin görüşlerinin belirlenmesi gerekmektedir. Geleneksel yapının hakim olduğu toplumumuzda özellikle aile, evlilik yaşamı, çalışma ve toplumsal yaşam alanlarında erkek ve kadına yüklenen rollerin üniversite öğrencileri tarafından nasıl bir anlam taşıdığının araştırılması son derece önemlidir (11). Ülkemizde üniversite öğrencileri ile yapılan çalışmalar incelendiğinde; öğrencilerin cinsiyet algısı, cinsiyet rollerine ilişkin tutumları ve etkileyen faktörler ele alınmıştır (4,7,8,14-17). Çalışmalarda cinsiyetin $(3,8,11,14,15)$, aile yapısının (17), ebeveynin eğitim durumunun $(3,7)$, kardeş sayısının $(3,10)$ ve ekonomik durumun (3) ögrrencinin toplumsal cinsiyet rolüne ilişkin tutumunu etkilediği bulunmuştur. Çalışmalarda kız cinsiyetin $(7,11,15)$, üç ve üzerinde kardeşe ve eğitimli ebeveyne sahibi olmanın $(4,7,10)$, gelişmiş ilde yaşamanın (10), çekirdek aile yapısına sahip olmanın (16) ve sağlıkla ilgili bölümde okumanın (18) toplumsal cinsiyet algısını olumlu etkilediği saptanmıştır. Bununla birlikte Atatürk Üniversitesi'nde 300 sosyal alan ögrencisi ile yapılan bir çalışmada toplumsal cinsiyet rollerine ilişkin geleneksel tutum puanları arttıkça şiddet eğilim puanlarının da artığı aile içi şiddete maruz kalanların daha geleneksel bakış açısına sahip olduğu saptanmıştır (7).

Toplumun gelişmesi ve ilerlemesine öncülük edecek üniversitelerin yetiştirdiği öğrencilerin toplumsal cinsiyet algısı ve cinsiyet rolleri yönünden daha eşitlikçi bir yaklaşıma sahip olması beklenmektedir. Buna karşı gerek yurtdışında gerekse ülkemizde üniversite öğrencilerinin toplumsal cinsiyet algısını belirlemeye yönelik yapılan araştırmalarda kadınların erkeklerde göre daha eşitlikçi bakış açısına sahipken, erkeklerin geleneksel bakış açılarını devam ettirdikleri görülmektedir $(1,14,19,20)$. Özellikle üniversitelerin sağlıkla ilgili bölümlerinin toplumla ve bireylerle sürekli etkileşim halinde olması ve toplum sağlığının gelişmesi için hizmet verdiği göz önünde bulundurulduğunda cinsiyet ayrımcılığına yönelik toplumsal farkındalığın gelişmesi ve cinsiyet eşitliğinin sağlanması için bu bölümlerde okuyan öğrencilere önemli sorumluluklar düşmekte ve öğrencilerin toplumsal cinsiyet eşitliğine ilişkin tutumlarının belirlenmesi önem taşımaktadır. Bu nedenle planlanan bu çalışmada Sağlık Bilimleri Fakültesi öğrencilerinin toplumsal cinsiyet eşitliği tutumlarının incelenmesi amaçlanmıştır.

\section{GEREÇ VE YÖNTEMLER Evren ve Örneklem}

Tanımlayıcı ve kesitsel tipte olan bu araştırmanın evrenini Manisa Celal Bayar Üniversitesi Sağlık Bilimleri Fakültesinde 2017-2018 güz yarıyılında kayıt yaptıran 2218 öğrenci oluşturmuştur. Araştırma örneklemi Epi info 2000 programı kullanılarak hesaplanmıştır. Evreni bilinen formül ile bilinmeyen prevalans \%50 alınarak, \%99 güven aralığında ve 0,05 kabul edilebilir örnekleme hatası ile minimum örneklem genişliği 511 olarak hesaplanmıştır. Bu çalışmaya 731 öğrenci katılmıştır.

\section{Veri Toplama Araçları}

Veri toplama formu iki bölümden oluşmaktadır. İlk bölümde öğrencilerin sosyo-demografik özellikleriyle ilgili 19 soru bulunmaktadır. Bu sorular öğrencilerin yaş1, cinsiyeti, doğum yeri, yaşadığı yer, sınıfi, mezun olunan lise türü, halen okumakta oldukları bölüm, kardeş sayısı, ebeveynlerin eğitim ve çalışma durumları, ailenin gelir durumu ve cinsiyet eşitliğine ilişkin daha önce bilgi, eğitim ve ders alma durumları gibi özellikleri içeren sorulardir.

İkinci bölümde “Toplumsal Cinsiyet Eşitliği Ölçeği” yer almaktadır. Bu ölçek 2017 yılında Gözütok, Toraman ve Acar Erdol (21) tarafindan geliştirilmiş beşli likert tipinde ve 13 maddeden oluşmaktadır. Ölçeğin Erkeği Üstün Gören Anlayış ile Kadını Erkeğe Bağımlı Kılan Anlayış olmak üzere iki boyutu bulunmaktadır. Ölçeğin 1, 6, 7, 9, 10, 11, 12 ve 13 numaralı maddeleri "Erkeği Üstün Gören Anlayış (EÜGA)" boyutunu oluşturmakta ve bu alt boyuttan yüksek puan almak erkeğin kadından üstünlüğünü, erkek egemenliğinin kabulü anlamına gelmektedir. Ölçeğin 2, 3, 4, 5 ve 8 numaralı maddeleri ise "Kadını Erkeğe Bağımlı Kılan Anlayış (KEBKA)" boyutunu temsil etmekte ve bu alt boyuttan yüksek puan 
almak aile içi ilişkide kadının erkeğe bağımlılığı, kadının kocasından izin alarak hareket etmesi gerektiğiyle ilgili görüş anlamına gelmektedir. Bu ölçeğin Cronbach alfa değeri Gözütok ve arkadaşları (21) tarafından 0,89 olarak belirlenmiştir.

\section{Veri Toplama Yöntemi}

Araştırmanın verileri Mart-Haziran 2018 tarihleri arasında toplanmıştır. Veriler toplanmadan önce çalışmanın amacı araştırmacılar tarafından öğrencilere açıklanarak aydınlatılmış onamları alınan öğrencilerden sınıfta veri toplama araçlarını kendilerinin doldurmaları istenerek veriler toplanmıştır. Verilerin toplanması yaklaşık olarak 15-20 dakika sürmüştür. Araştırma, soru formlarını eksiksiz dolduran 731 öğrenci ile tamamlanmıştır.

\section{Araştırmanın Etiği}

Manisa Celal Bayar Üniversitesi Tıp Fakültesi Sağlık Bilimleri Etik Kurulu'ndan araştırmanın yapılabilmesi için etik kurul onayı alınmıştır (tarih: 26/01/2018, sayı: 5453). Araştırmanın yürütülebilmesi için Manisa Celal Bayar Üniversitesi Sağlı Bilimleri Fakültesi Dekanlığından yazılı izin alınmıştır (tarih: 19/03/2018, sayı: 1046). Araştırmaya katılan öğrencilerden yazılı bilgilendirilmiş onam alınmıştır. "Toplumsal Cinsiyet Eşitliği Ölçeği”ni bu araştırmada kullanabilmek için ölçeği geliştiren ekipte yer alan Tuba ACAR ERDOL'dan elektronik posta yolu ile yazılı izin alınmıştır. Yapılan çalışmada, araştırma ve yayın etiğine uyulmuştur.

\section{İstatistiksel Analiz}

Verilerin analizinde SPSS $(15,0)$ programı kullanılmıştır. Verileri çözümlemede tanımlayıcı özellikler sayı, yüzde, ortanca ve IQR (Interquartile Range-çeyrekler arası genişlik) olarak sunulmuştur. Sürekli değişkenlerin normallik varsayımını sağlama durumu KolmogorovSmirnov ve Shapiro-Wilk testleri ile değerlendirilmiştir. Normallik varsayımı sağlanmadığından sürekli değişkenlerin tek değişkenli analizlerinde Mann-Whitney U, Kruskal-Wallis ve post hoc analizlerde Bonferroni Düzeltmeli Mann-Whitney U testi kullanılmıştır. Toplumsal Cinsiyet Eşitliği Ölçeği'nin Cronbach alfa değeri hesaplanmıştır.

\section{BULGULAR}

\section{Öğrencilerin Tanıtıcı Özellikleri ile Toplumsal Cinsiyet Eşitliği Ölçeği Alt Boyutlarına İlişkin Bulgular}

Araştırmada öğrencilerin \%73,3'ü kadın, \%29,7'si hemşirelik bölümünde okumakta, \%29,1'i birinci sınıf öğrencisidir. Araştırmaya katılan öğrencilerin yaş ortalamas1 20,9 $\pm 1,8$ (min:17, maks:32) olup \%53,8'i 21 yaş ve üzerindedir. Katılımcıların \%33,3’ü Marmara bölgesinde doğmuş, bireylerin yaklaşık yarısı (\%51) en uzun süre ilde yaşadığını belirtmiştir. Öğrencilerin çoğunluğu $(\% 62,5)$ anadolu lisesi mezunudur. Öğrencilerin \%66,9'u üniversiteyi kazanmadan önce ailesi ile yaşadığını belirtirken \%55,1'i üniversiteyi kazandıktan sonra yurtta yaşamaktadır.

EÜGA puan ortancası erkek öğrencilerde (ortanca: 16, IQR: 11) kadın öğrencilere (ortanca: 9, IQR: 5) göre, KEBKA puan ortancası erkek öğrencilerde (ortanca: 13, IQR: 7) kadın öğrencilere (ortanca: 9, IQR: 6,5) göre istatistiksel olarak anlamlı düzeyde yüksek bulunmuştur $(\mathrm{p}<0,0001)$. Öğrencilerin okudukları bölümlere göre
EÜGA $(p=0,010) \quad(a, d>c$ için $p<0,0083)$ ve KEBKA $(\mathrm{p}<0,0001) \quad(a, b, d>c$ için $\mathrm{p}<0,0083)$ puan ortancaları bakımından istatistiksel olarak anlamlı bir fark vardır. EÜGA puan ortancası Hemşirelik (ortanca: 10, IQR: 8) ve Fizyoterapi ve Rehabilitasyon (FTR) (ortanca: 10, IQR: 8,5) öğrencilerinde Sosyal Hizmet (ortanca: 9, IQR: 6) öğrencilerine göre, KEBKA puan ortancası hemşirelik (ortanca: 10, IQR: 7), FTR (ortanca: 10, IQR: 8) ve ebelik öğrencilerinde (ortanca: 10, IQR: 6) sosyal hizmet (ortanca: 8, IQR: 6) öğrencilerine göre daha yüksek saptanmıştır. Marmara bölgesinde doğan öğrencilerin EÜGA puan ortanca değeri Akdeniz bölgesi hariç diğer bölgelerde doğan öğrencilere göre düşük belirlenmiş olup gruplar arasında istatistiksel olarak anlamlı fark saptanmıştır $(p=0,010) \quad(b, c, d, e, g>f$ için $p \leq 0,00238)$. Doğu Anadolu (ortanca: 11, IQR: 6) Bölgesinde doğan öğrencilerin KEBKA puan ortancasının Marmara bölgesinde doğan öğrencilere (ortanca: 8, IQR: 6) göre istatistiksel olarak daha yüksek olduğu bulunmuştur $(p=0,013) \quad(d>f$ için $p \leq 0,00238)$. En uzun süre köyde yaşayan öğrencilerin EÜGA $(p=0,007)$ puan ortancası ilde yaşayan öğrencilere göre (c $>a$ için $p=0,002)$, KEBKA $(p=0,012)$ puan ortancası il ve ilçede yaşayan öğrencilere göre $(c>a, b$ için $p<0,016)$ yüksek olup istatistiksel olarak anlamlı olduğu saptanmıştır. Şu an ailesiyle yaşayan öğrencilerin EÜGA $(p<0,0001)$ (c >a için $\mathrm{p}<0,0083)$ ve KEBKA $(\mathrm{p}<0,0001)$ (c $>$ a için $\mathrm{p}<0,0083)$ puan ortancası arkadaşlarıyla yaşayan ögrencilere göre daha düşük saptanmıştır.

Öğrencilerin sınıfı, yaş grubu ve mezun olunan lise tipine göre KEBKA ve EÜGA puan ortanca değerleri açısından istatistiksel olarak anlamlı bir fark bulunmamıştır ( $>0,05)$. Yapılan ileri analizlerde (Bonferroni Düzeltmeli Mann-Whitney $U$ testi) öğrencilerin üniversite öncesi yaşadıkları yer ile EÜGA ve KEBKA puan ortancası arasında istatistiksel olarak anlamlı bir fark bulunmamıştır (post-hoc $\mathrm{p}>0,0083$ ) (Tablo 1).

Öğrencilerin Ailelerinin Tanıtıcı Özellikleri ile Toplumsal Cinsiyet Eşitliği Ölçeği Alt Boyutlarına İlişkin Bulgular

Katılımcıların \%45,1'inin annesi ve \%34,7'sinin babası ilkokul mezunudur. Öğrencilerin çoğunluğunun (\%83) annesi, \%30,5'inin babası çalışmamaktadır. Öğrencilerin $\% 65,9$ 'u aile gelirinin giderlerine eşit olduğunu belirtmiştir.

Okuryazar olmayan anneye sahip olan öğrencilerin EÜGA $(p<0,0001)(a>e, f$ için $p<0,0033)$ puan ortancas1 annesi lise ve yükseköğretim mezunu olan öğrencilere göre yüksek olup aradaki fark istatistiksel olarak anlamlı bulunmuştur. KEBKA $(\mathrm{p}<0,0001) \quad(\mathrm{a}>\mathrm{c}, \mathrm{d}, \mathrm{e}, \mathrm{f})$ puan ortanca değeri annesi okuryazar olmayan grupta annesi ilkokul ve üzeri eğitim alan gruba göre yüksek ve aradaki fark istatistiksel olarak anlamlı saptanmıştır. Babanın eğitim durumu ile öğrencilerin EÜGA $(p=0,001)(a>d)$ ve KEBKA $(p=0,005) \quad(a>d)$ puan ortancası arasında istatistiksel olarak anlamlı fark saptanmıştır. Annenin çalışma durumu ile EÜGA puan ortancaları arasında istatistiksel olarak anlamlı fark saptanmamıştır ( $p>0,05)$. KEBKA puan ortancası annesi çalışmayan öğrencilerde (ortanca: 10, IQR: 7) annesi çalışan öğrencilere göre (ortanca: 8, IQR: 7) yüksek bulunmuştur $(\mathrm{p}=0,004)$. Öğrencilerin kardeş sayısı, babanın çalışma durumu ve ailenin gelir durumuna göre KEBKA ve EÜGA puan 
Tablo 1. Öğrencilerin tanıtıcı özellikleri ile toplumsal cinsiyet eşitliği ölçeği alt boyutlarından aldıkları puanların dağılımı

\begin{tabular}{|c|c|c|c|c|c|}
\hline \multirow{2}{*}{ Tanıtıcı özellikler } & \multirow[b]{2}{*}{ n (\%) } & \multicolumn{2}{|c|}{$\begin{array}{l}\text { Erkeği Üstün Gören Anlayış } \\
\text { (EÜGA) }\end{array}$} & \multicolumn{2}{|c|}{$\begin{array}{c}\text { Kadını Erkeğe Bağımlı } \\
\text { Kılan Anlayıș (KEBKA) }\end{array}$} \\
\hline & & $\begin{array}{c}\text { Ortanca } \\
\text { (IQR) }\end{array}$ & Test & $\begin{array}{c}\text { Ortanca } \\
\text { (IQR) }\end{array}$ & Test \\
\hline $\begin{array}{l}\text { Cinsiyet } \\
\text { Erkek } \\
\text { Kadın }\end{array}$ & $\begin{array}{l}195(26,7) \\
536(73,3)\end{array}$ & $\begin{array}{l}16,0(11,0) \\
9,0(5,0)\end{array}$ & $\begin{array}{c}\text { MU }=28486,00 \\
\mathbf{p}<\mathbf{0 , 0 0 0 1}\end{array}$ & $\begin{array}{l}13,0(7,0) \\
9,0(6,5)\end{array}$ & $\begin{array}{c}\mathrm{MU}=29973,5 \\
\mathbf{p}<\mathbf{0 , 0 0 0 1}\end{array}$ \\
\hline $\begin{array}{l}\text { Bölüm } \\
\text { Hemşirelik (a) } \\
\text { Ebelik (b) } \\
\text { Sosyal Hizmet (c) } \\
\text { Fizyoterapi ve } \\
\text { Rehabilitasyon (d) }\end{array}$ & $\begin{array}{l}217(29,7) \\
157(21,5) \\
164(22,4) \\
193(26,4)\end{array}$ & $\begin{array}{c}10,0(8,0) \\
10,0(7,0) \\
9,0(6,0) \\
10,0(8,5)\end{array}$ & $\begin{array}{c}\mathrm{KW} \chi^{2}=11,438 \\
\mathbf{p}=\mathbf{0 , 0 1 0} \\
\mathbf{a , d}>\mathbf{c}\end{array}$ & $\begin{array}{c}10,0(7,0) \\
10,0(6,0) \\
8,0(6,0) \\
10,0(8,0)\end{array}$ & $\begin{array}{c}\mathrm{KW} \chi^{2}=36,346 \\
\mathbf{p}<\mathbf{0 , 0 0 0 1} \\
\mathbf{a , b , d}>\mathbf{c}\end{array}$ \\
\hline $\begin{array}{l}\text { Sinıf } \\
\text { 1. sinif } \\
\text { 2. sinif } \\
\text { 3. sinif } \\
\text { 4. sinif } \\
\end{array}$ & $\begin{array}{l}213(29,1) \\
155(21,2) \\
194(26,5) \\
169(23,1) \\
\end{array}$ & $\begin{array}{l}10,0(7,0) \\
10,0(8,0 \\
10,0(8,0) \\
10,0(9,0) \\
\end{array}$ & $\begin{array}{c}\mathrm{KW} \chi^{2}=0,282 \\
\mathrm{p}=0,963\end{array}$ & $\begin{array}{c}10,0(7,0) \\
10,0(6,0) \\
10,0(7,0) \\
9,0(8,5) \\
\end{array}$ & $\begin{array}{c}\mathrm{KW} \chi^{2}=2,833 \\
\mathrm{p}=0,418\end{array}$ \\
\hline $\begin{array}{l}\text { Yaş } \\
20 \text { yaş ve altı } \\
21 \text { yaş ve üzeri } \\
\end{array}$ & $\begin{array}{l}338(46,2) \\
393(53,8)\end{array}$ & $\begin{array}{l}10,0(7,0) \\
10,0(8,0)\end{array}$ & $\begin{array}{c}\mathrm{MU}=62810,500 \\
\mathrm{p}=0,194\end{array}$ & $\begin{array}{l}10,0(7,0) \\
9,0(7,0)\end{array}$ & $\begin{array}{c}\mathrm{MU}=66382,500 \\
\mathrm{p}=0,990\end{array}$ \\
\hline $\begin{array}{l}\text { Doğduğu bölge* } \\
\text { Akdeniz (a) } \\
\text { Güneydoğu Anadolu (b) } \\
\text { Ege (c) } \\
\text { Doğu Anadolu (d) } \\
\text { İç Anadolu (e) } \\
\text { Marmara (f) } \\
\text { Karadeniz (g) } \\
\end{array}$ & $\begin{array}{c}77(10,7) \\
49(6,8) \\
174(24,1) \\
68(9,4) \\
61(8,4) \\
241(33,3) \\
53(7,3) \\
\end{array}$ & $\begin{array}{c}10,0(8,0) \\
12,0(9,5) \\
11,0(8,0) \\
11,5(9,0) \\
12,0(8,5) \\
9,0(4,0) \\
11,0(8,0) \\
\end{array}$ & $\begin{aligned} \mathrm{KW} \chi^{2} & =38,403 \\
\mathbf{p} & =\mathbf{0 , 0 1 0} \\
\mathbf{b , c , d , e , g}>\mathbf{f} & \end{aligned}$ & $\begin{array}{c}10,0(7,0) \\
10,0(8,0) \\
10,0(7,0) \\
11,0(6,0) \\
11,0(7,0) \\
8,0(6,0) \\
11,0(8,0) \\
\end{array}$ & $\begin{array}{c}\mathrm{KW} \chi^{2}=17,750 \\
\mathbf{p}=\mathbf{0 , 0 1 3} \\
\mathbf{d}>\mathbf{f}\end{array}$ \\
\hline $\begin{array}{l}\text { En uzun yaşadığı yer } \\
\text { İl (a) } \\
\text { İlçe (b) } \\
\text { Köy (c) }\end{array}$ & $\begin{array}{l}373(51,0) \\
254(34,7) \\
104(14,2) \\
\end{array}$ & $\begin{array}{c}9,0(7,0) \\
10,0(8,0) \\
11,0(9,0) \\
\end{array}$ & $\begin{array}{c}\mathrm{KW} \chi^{2}=10,068 \\
\mathbf{p}=\mathbf{0 , 0 0 7} \\
\mathbf{c}>\mathbf{a}\end{array}$ & $\begin{array}{c}10,0(7,0) \\
9,0(7,0) \\
11(6,8) \\
\end{array}$ & $\begin{array}{c}\mathrm{KW} \chi^{2}=8,807 \\
\mathbf{p}=\mathbf{0 , 0 1 2} \\
\mathbf{c}>\mathbf{a , b}\end{array}$ \\
\hline $\begin{array}{l}\text { Mezun olunan lise } \\
\text { Lise } \\
\text { Anadolu Lisesi } \\
\text { Fen Lisesi } \\
\text { Özel Lise } \\
\text { Meslek Lisesi } \\
\text { İmam Hatip Lisesi } \\
\text { Anadolu Ögretmen Lisesi }\end{array}$ & $\begin{array}{c}86(11,8) \\
457(62,5) \\
34(4,7) \\
31(4,2) \\
53(7,3) \\
12(1,6) \\
58(7,9) \\
\end{array}$ & $\begin{array}{c}10,0(8,0) \\
10,0(8,0) \\
9,0(8,3) \\
10,0(8,3) \\
9,0(3,0) \\
13,5(5,8) \\
11,0(9,3) \\
\end{array}$ & $\begin{array}{c}\mathrm{KW} \chi^{2}=8,350 \\
\mathrm{p}=0,080\end{array}$ & $\begin{array}{c}10,0(8,0) \\
10,0(7,0) \\
9,0(7,0) \\
9,0(8,0) \\
8,0(6,0) \\
11,0(3,0) \\
9,5(9,0) \\
\end{array}$ & $\begin{array}{c}\mathrm{KW} \chi^{2}=9,524 \\
\mathrm{p}=0,146\end{array}$ \\
\hline $\begin{array}{l}\text { Üniversite öncesi yaşadığı } \\
\text { yer } \\
\text { Geniş aile (a) } \\
\text { Çekirdek aile (b) } \\
\text { Yurt (c) } \\
\text { Tek başına (d) }\end{array}$ & $\begin{array}{c}210(28,7) \\
489(66,9) \\
20(2,7) \\
12(1,6) \\
\end{array}$ & $\begin{array}{c}11,0(9,0) \\
10,0(7,0) \\
10,0(10,5) \\
18,5(14,0) \\
\end{array}$ & $\begin{array}{c}\mathrm{KW} \chi^{2}=10,03 \\
\mathrm{p}=0,018 \\
\mathrm{a}>\mathrm{b} \\
\mathrm{p}^{* *}=0,011\end{array}$ & $\begin{array}{c}10,0(8,0) \\
9,0(6,5) \\
11,0(8,7) \\
14(9,3) \\
\end{array}$ & $\begin{array}{c}\mathrm{KW} \chi^{2}=10,737 \\
\mathrm{p}=0,013 \\
\mathrm{a}>\mathrm{b} \\
\mathrm{p}^{* *}=0,017\end{array}$ \\
\hline $\begin{array}{l}\text { Şu anda yaşadığı yer } \\
\text { Aile (a) } \\
\text { Tek başına (b) } \\
\text { Arkadaşları ile birlikte (c) } \\
\text { Yurt (d) }\end{array}$ & $\begin{array}{c}190(26,0) \\
23(3,1) \\
115(15,7) \\
403(55,1)\end{array}$ & $\begin{array}{c}9,0(4,0) \\
10,0(10,0) \\
15,0(11,0) \\
10,0(7,0)\end{array}$ & $\begin{array}{c}\mathrm{KW} \chi^{2}=27,053 \\
\mathbf{p}<\mathbf{0 , 0 0 0 1} \\
\mathbf{c}>\mathbf{a}\end{array}$ & $\begin{array}{l}9,0(5,0) \\
11,0(7,0) \\
13,0(7,0) \\
10,0(7,0)\end{array}$ & $\begin{array}{c}\mathrm{KW} \chi^{2}=28,200 \\
\mathbf{p}<\mathbf{0 , 0 0 0 1} \\
\mathbf{c}>\mathbf{a}\end{array}$ \\
\hline
\end{tabular}


Tablo 2. Öğrencilerin ailelerinin tanıtıcı özellikleri ile toplumsal cinsiyet eşitliği ölçeği alt boyutlarından aldıkları puanların dağılımı

\begin{tabular}{|c|c|c|c|c|c|}
\hline \multirow[t]{2}{*}{ Tanıtıcı özellikler } & \multirow[t]{2}{*}{ n (\%) } & \multicolumn{2}{|c|}{$\begin{array}{l}\text { Erkeği Üstün Gören Anlayış } \\
\text { (EÜGA) }\end{array}$} & \multicolumn{2}{|c|}{$\begin{array}{c}\text { Kadını Erkeğe Bağımlı Kılan } \\
\text { Anlayıș (KEBKA) }\end{array}$} \\
\hline & & $\begin{array}{c}\text { Ortanca } \\
\text { (IQR) }\end{array}$ & Test & $\begin{array}{c}\text { Ortanca } \\
\text { (IQR) }\end{array}$ & Test \\
\hline $\begin{array}{l}\text { Annenin eğitim durumu } \\
\text { Okur-yazar değil (a) } \\
\text { Okur-yazar (b) } \\
\text { İlkokul (c) } \\
\text { Ortaokul (d) } \\
\text { Lise mezunu (e) } \\
\text { Yükseköğretim (f) } \\
\end{array}$ & $\begin{array}{c}63(8,6) \\
55(7,5) \\
330(45,1) \\
118(16,1) \\
119(16,3) \\
46(6,3) \\
\end{array}$ & $\begin{array}{c}13,0(10,0) \\
11,0(9,0) \\
10,0(8,0) \\
10,0(8,0) \\
9,0(5,0) \\
9,0(5,3) \\
\end{array}$ & $\begin{array}{c}\mathrm{KW} \chi^{2}=24,941 \\
\mathbf{p}<\mathbf{0 , 0 0 0 1} \\
\mathbf{a}>\mathbf{e , f}\end{array}$ & $\begin{array}{c}12,0(6,0) \\
10,0(8,0) \\
10,0(7,0 \\
10,0(6,0) \\
9,0(8,0) \\
8,0(5,3) \\
\end{array}$ & $\begin{array}{c}\mathrm{KW} \chi^{2}=29,113 \\
\mathbf{p}<\mathbf{0 , 0 0 0 1} \\
\mathbf{a}>\mathbf{c , d}, \mathbf{e , f}\end{array}$ \\
\hline $\begin{array}{l}\text { Babanın eğitim } \\
\text { durumu** } \\
\text { Okur-yazar (a) } \\
\text { İlkokul (b) } \\
\text { Ortaokul (c) } \\
\text { Lise mezunu (d) } \\
\text { Yükseköğretim (e) } \\
\end{array}$ & $\begin{array}{c}29(4,0) \\
252(34,7) \\
144(19,8) \\
179(24,6) \\
123(16,9) \\
\end{array}$ & $\begin{array}{c}14,0(18,0) \\
10,0(8,0) \\
10,0(8,0) \\
9,0(7,0) \\
10,0(8,0) \\
\end{array}$ & $\begin{array}{c}\mathrm{KW} \chi^{2}=15,348 \\
\mathbf{p}=\mathbf{0 , 0 0 4} \\
\mathbf{a}>\mathbf{d}\end{array}$ & $\begin{array}{c}13,0(8,5) \\
10,0(6,7) \\
10,0(6,0) \\
9,0(8,0) \\
9,0(7,0) \\
\end{array}$ & $\begin{array}{c}\mathrm{KW} \chi^{2}=9,871 \\
\mathbf{p}=\mathbf{0 , 0 4 3} \\
\mathbf{a}>\mathbf{d}\end{array}$ \\
\hline $\begin{array}{l}\text { Annenin çalışma } \\
\text { durumu } \\
\text { Çalışan } \\
\text { Çalışmayan } \\
\end{array}$ & $\begin{array}{l}124(17,0) \\
607(83,0)\end{array}$ & $\begin{array}{c}9,0(7,0) \\
10,0(8,0)\end{array}$ & $\begin{array}{c}\mathrm{MU}=34514,500 \\
\mathrm{p}=0,136\end{array}$ & $\begin{array}{c}8,0(7,0) \\
10,0(7,0)\end{array}$ & $\begin{array}{c}\mathrm{MU}=30637,500 \\
\mathbf{p}=\mathbf{0 , 0 0 1}\end{array}$ \\
\hline $\begin{array}{l}\text { Babanın çalışma } \\
\text { durumu } \\
\text { Çalışan } \\
\text { Çalışmayan } \\
\text { Yaşamayan } \\
\end{array}$ & $\begin{array}{c}494(67,6) \\
223(30,5) \\
14(1,9) \\
\end{array}$ & $\begin{array}{c}10,0(8,0) \\
9,0(8,0) \\
10,5(6,7) \\
\end{array}$ & $\begin{array}{c}\mathrm{KW} \chi^{2}=1,265 \\
\mathrm{p}=0,531\end{array}$ & $\begin{array}{l}10,0(7,0) \\
9,0(7,0) \\
8,5(6,0) \\
\end{array}$ & $\begin{array}{c}\mathrm{KW} \chi^{2}=3,752 \\
\mathrm{p}=0,153\end{array}$ \\
\hline $\begin{array}{l}\text { Kardeş sayısı } \\
\text { Tek çocuk (a) } \\
2 \text { kardeş (b) } \\
3 \text { ve daha fazla kardeş (c) }\end{array}$ & $\begin{array}{c}41(5,6) \\
282(38,6) \\
408(55,8) \\
\end{array}$ & $\begin{array}{c}9,0(5,5) \\
9,0(7,0) \\
11,0(8,0)\end{array}$ & $\begin{array}{c}\mathrm{KW} \chi^{2}=0,776 \\
\mathrm{p}=0,378\end{array}$ & $\begin{array}{c}7,0(7,5) \\
8,5(7,0) \\
10,0(7,0) \\
\end{array}$ & $\begin{array}{c}\mathrm{KW} \chi^{2}=1,183 \\
\mathrm{p}=0,277\end{array}$ \\
\hline $\begin{array}{l}\text { Ailenin gelir durumu } \\
\text { Gelir giderden az } \\
\text { Gelir gidere eşit } \\
\text { Gelir giderden fazla } \\
\end{array}$ & $\begin{array}{l}116(15,9) \\
482(65,9) \\
133(18,2) \\
\end{array}$ & $\begin{array}{c}10,0(8,0) \\
10,0(8,0) \\
9,0(7,5) \\
\end{array}$ & $\begin{array}{c}\mathrm{KW} \chi^{2}=1,623 \\
\mathrm{p}=0,444\end{array}$ & $\begin{array}{c}9,0(7,0) \\
10,0(6,0) \\
8,0(8,0)\end{array}$ & $\begin{array}{c}\mathrm{KW} \chi^{2}=4,618 \\
\mathrm{p}=0,099\end{array}$ \\
\hline
\end{tabular}

Tablo 3. Öğrencilerin toplumsal cinsiyet konusunda eğitim ve ders alma durumu ile toplumsal cinsiyet eşitliği ölçeği alt boyutlarından aldıkları puanların dağılım

\begin{tabular}{|c|c|c|c|c|c|}
\hline \multirow{2}{*}{ Eğitim ve Ders Alma } & \multirow{2}{*}{$n(\%)$} & \multicolumn{2}{|c|}{$\begin{array}{l}\text { Erkeği Üstün Gören Anlayış } \\
\text { (EÜGA) }\end{array}$} & \multicolumn{2}{|c|}{$\begin{array}{c}\text { Kadını Erkeğe Bağımlı Kılan } \\
\text { Anlayış (KEBKA) }\end{array}$} \\
\hline & & Ortanca (IQR) & Test & Ortanca(IQR) & Test \\
\hline $\begin{array}{l}\text { Toplumsal cinsiyet } \\
\text { kavramını duyma } \\
\text { durumu } \\
\text { Duyan } \\
\text { Duymayan }\end{array}$ & $\begin{array}{l}622(85,1) \\
109(14,9)\end{array}$ & $\begin{array}{c}10,0(7,0) \\
12,0(11,5)\end{array}$ & $\begin{array}{c}M U=26096,000 \\
\mathbf{p}<\mathbf{0 , 0 0 0 1}\end{array}$ & $\begin{array}{c}9,0(7,0) \\
11,0(7,0)\end{array}$ & $\begin{array}{c}\mathrm{MU}=25834,5 \\
\mathbf{p}<\mathbf{0 , 0 0 0 1}\end{array}$ \\
\hline $\begin{array}{l}\text { Toplumsal cinsiyet } \\
\text { konusunda eğitime } \\
\text { katılma durumu } \\
\text { Katılan } \\
\text { Katılmayan } \\
\end{array}$ & $\begin{array}{l}222(30,4) \\
509(69,6)\end{array}$ & $\begin{array}{c}9,0(7,0) \\
10,0(8,0)\end{array}$ & $\begin{array}{c}M U=50298,500 \\
\mathbf{p}=\mathbf{0 , 0 1 5}\end{array}$ & $\begin{array}{c}8,0(7,0) \\
10,0(6,5)\end{array}$ & $\begin{aligned} \mathrm{MU} & =47687,5 \\
\mathbf{p} & =\mathbf{0 , 0 0 1}\end{aligned}$ \\
\hline $\begin{array}{l}\text { Toplumsal cinsiyet eşitliği } \\
\text { dersi alma durumu } \\
\text { Alan } \\
\text { Almayan }\end{array}$ & $\begin{array}{l}156(21,3) \\
575(78,7)\end{array}$ & $\begin{array}{l}9,0(7,0) \\
10,0(8,0)\end{array}$ & $\begin{array}{c}\mathrm{MU}=39503,000 \\
\mathbf{p}=\mathbf{0 , 0 1 9}\end{array}$ & $\begin{array}{l}8,0(7,0) \\
10,0(6,0)\end{array}$ & $\begin{aligned} \mathrm{MU} & =38124,0 \\
\mathbf{p} & =\mathbf{0 , 0 0 4}\end{aligned}$ \\
\hline
\end{tabular}


ortanca değerleri açısından istatistiksel olarak anlamlı bir fark saptanmamıştır ( $\mathrm{p}>0,05)$ (Tablo 2).

\section{Öğrencilerin Toplumsal Cinsiyet Konusunda Eğitim Alma Durumu ile Toplumsal Cinsiyet Eşitliği Ölçeği Alt Boyutlarına İlişkin Bulgular}

Katılımcıların çoğunluğu $(\% 85,1)$ toplumsal cinsiyet kavramını duymuş, \%78,7'si toplumsal cinsiyet dersini almamış ve \%69,6'sı toplumsal cinsiyetle ilgili eğitim almamıştır.

Toplumsal cinsiyet kavramını duyan öğrencilerde EÜGA puan ortancası duymayan öğrencilere göre düşük olup puanlar sirasiyla 10 ve 12 ' $\operatorname{dir}(\mathrm{p}<0,0001)$. KEBKA puan ortancas1 toplumsal cinsiyet kavramını duymayan öğrencilerde (ortanca: 11, IQR: 7) duyan öğrencilere (ortanca: 9, IQR: 7) göre yüksek olup iki grup arasında istatistiksel olarak anlamlı fark saptanmıştır $(p<0,0001)$. Toplumsal cinsiyet konusunda eğitime katılan öğrencilerin EÜGA puan ortancası 9 (IQR: 7) katılmayanların 10 (IQR: 8)'dur. İki grup arasından EÜGA puan ortancası açısından istatistiksel olarak anlamlı fark bulunmuştur $(\mathrm{p}=0,015)$. KEBKA puan ortancası toplumsal cinsiyet ile ilgili eğitime katılanlarda (ortanca: 8, IQR: 7) katılmayanlara göre (ortanca: 10 IQR: 6,5) istatistiksel olarak anlamlı düzeyde düşüktür $(p=0,001)$. Toplumsal cinsiyet eşitliği dersi alma durumları ile EÜGA ile KEBKA puan ortancaları incelendiğinde EÜGA $(p=0,019)$ ve $\operatorname{KEBKA}(p=0,004)$ puan ortancaları toplumsal cinsiyet dersi alan öğrencilerde almayan öğrencilere göre istatistiksel olarak anlamlı düzeyde düşük bulunmuştur (Tablo 3). Yaptığımız bu çalışmada Toplumsal Cinsiyet Eşitliği Ölçeği'nin Cronbach alfa değeri 0,94 olarak bulunmuştur.

\section{TARTISMA}

$\mathrm{Bu}$ çalışma Sağlık Bilimleri Fakültesi öğrencilerinin toplumsal cinsiyet eşitliği tutumlarını değerlendirmek amacıyla gerçekleştirilmiştir. Literatür incelendiğinde, bu konuda üniversite öğrencileri ile yapılan çalışmalar bulunmakla birlikte $(3-5,7,8,11,15,16,18)$ Toplumsal Cinsiyet Eşitliği Ölçeği kullanılarak yapılan basılı bir çalışma bu çalışmanın yazım aşamasında bulunmamaktadır. $\mathrm{Bu}$ nedenle bu araştırmanın yeni bir ölçek olan Toplumsal Cinsiyet Eşitliği Ölçeği kullanılarak geniş bir öğrenci popülasyonunda yürütülmesi $(n=731)$ literatüre yeni bilgi katması açısından önemlidir. $\mathrm{Bu}$ araştırmada öğrencilerin çoğunluğu kadın $(\% 73,3)$, yaklaşık yarısından fazlası 21 yaş ve üzerinde, üçte biri Marmara bölgesinde doğmuş, ebeveynlerinin çoğunluğu ilkokul mezunu ve yarısından fazlası yurtta yaşamaktadır. Öğrencilerin büyük çoğunluğu toplumsal cinsiyet kavramını duymasına rağmen yaklaşı beşte biri toplumsal cinsiyet ile ilgili ders almış ve üçte biri toplumsal cinsiyet ile ilgili bir eğitime katılmıştır.

\section{Öğrencilerin Tanıtıcı Özellikleri ile Toplumsal} Cinsiyet Eşitliği Ölçeği Alt Boyutları Arasındaki İlişki $\mathrm{Bu}$ araştırmada kız ögrencilerin toplumsal cinsiyet eşitliği ölçeğinde KEBKA ve EÜGA puan ortancalarının erkek öğrencilere göre daha düşük olduğu belirlenmiştir. $\mathrm{Bu}$ bulgunun nedeni fakültemiz erkek öğrencilerinin büyük çoğunluğunun ülkemizin doğu bölgesinden gelmeleri ve daha geleneksel bir tutuma sahip olmasindan kaynaklanabilir. Literatür incelendiğinde bu konuda
Kars'ta soru formunda yer alan önermelerle (22) Erzurum'da Toplumsal Cinsiyet Rollerine İlişkin Tutum Ölçeği (7) ve Cinsiyet Eşitliği Ölçeği (18), Ankara’da literatüre dayalı soru formu (11), İzmir'de Cinsiyet Eşitliği Ölçeği (23) ve Bir Kamu Üniversitesi (16), Karabük (24) ve Bartın'da Toplumsal Cinsiyet Algısı Ölçeği (25) kullanılarak yürütülen çalışmalarda bu araştırma bulguları ile benzer sonuçlar saptanmıştır. $\mathrm{Bu}$ çalışma bulgularına zit olarak Gaziantep (8) ve Düzce'de (3) Toplumsal Cinsiyet Rolleri Tutum Ölçeği kullanılarak yapılan çalışmalarda erkeklerin kızlardan daha eşitlikçi tutuma sahip oldukları bulunmuştur. Toplumsal Cinsiyet Rolleri Tutum Ölçeği kullanılarak İstanbul'da yapılan çalışmada erkek öğrencilerin kız öğrencilerden daha çok eşitlikçi tutuma sahip oldukları bulunmuş ancak aradaki farkın anlamlı olmadığı saptanmıştır (4).

Eğitim görülen bölüm ve alınan derslerin öğrencilerin cinsiyet rolleri tutumlarını etkileyebildiği literatürde vurgulanmaktadır. Bu çalışmada sosyal hizmet bölümü öğrencilerinin diğer bölümde okuyan öğrencilere göre daha eşitlikçi tutum sergiledikleri (KEBKA ve EÜGA puan ortancalarının daha düşük olduğu) bunu sırasıyla ebelik, hemşirelik ve FTR bölümü öğrencilerinin izledikleri saptanmıştır. $\mathrm{Bu}$ çalışmanın yürütüldüğü fakültede hemşirelik bölümünde toplumsal cinsiyet eşitliği, ebelik bölümünde kadın sağlığ1 ve sosyal konular, sosyal hizmet bölümünde toplumsal cinsiyet ve sosyal hizmet ismiyle seçmeli ders bulunmakta olup FTR bölümünde bu ders bulunmamaktadır. $\mathrm{Bu}$ bulgunun nedeni sosyal hizmet bölümünde okuyan öğrencilerin ders içeriğinde toplumsal cinsiyet derslerinin daha fazla bulunmasından kaynaklanabilir. Uçtu ve Karahan'ın (24) çalışmasında çocuk gelişimi ve ebelik öğrencilerinin toplumsal cinsiyet algısının hemşirelik ve FTR öğrencilerinden daha olumlu olduğu bunun aksine Kömürcü ve arkadaşlarının (4) çalışmasında ebelik öğrencilerinin hemşirelik öğrencilerine göre daha geleneksel tutuma sahip oldukları bulunmuştur.

$\mathrm{Bu}$ araştırmada Marmara bölgesinde doğan öğrencilerin daha eşitlikçi tutuma sahip oldukları (KEBKA ve EÜGA puan ortancalarının daha düşük olduğu) ve en uzun süre köyde yaşayan öğrencilerin daha geleneksel tutuma sahip oldukları (KEBKA ve EÜGA puan ortancalarının yüksek olduğu) belirlenmiştir. Ankara'da yürütülen bir çalışmada ilkokulu bitirinceye kadar en uzun süre az gelişmiş düzeye sahip ilde yaşayan öğrencilerin orta gelişmiş ve gelişmiş düzeye sahip ilde yaşayan öğrencilerden daha geleneksel bakış açısına sahip oldukları bulunmuştur (10). Türkiye Sosyo-Ekonomik Gelişmişlik Sıralaması Araştırması 2011 sonuçlarına göre ülkemizin batısı doğusuna göre daha fazla gelişim göstermekte olup çalışma bulguları gelişmiş illerde doğan öğrencilerin daha eşitlikçi bakış açısına sahip olduklarını göstermektedir. $\mathrm{Bu}$ çalışma bulgularına zıt olarak Giresun'da yürütülen bir çalışmada yaşamlarının çoğunu köyde geçirenlerin şehirde geçirenlere göre daha eşitlikçi oldukları bulunmuş, şehir yaşamında cinsiyet rolleri tutumlarında önemli değişiklikler olmakla birlikte kadınların halen toplumsal cinsiyet rol kalıplarına göre değerlendirildiği vurgulanmıştır (17).

$\mathrm{Bu}$ çalışmada mezun olunan lise tipi ile toplumsal cinsiyet eşitliği ölçeği alt boyutları arasında ilişki bulunmamıştır. Ankara'da (10) yapılan çalışmada 
öğrencilerin mezun oldukları lisenin toplumsal cinsiyet rollerine ilişkin tutumlarını etkilemediği, Erzurum'da (18) yapılan bir çalışmada ise süper lise/anadolu liselerinden mezun olanların diğer lise türlerinden mezun olanlara göre eşitlikçi cinsiyet tutumlarının daha yüksek düzeyde olduğu saptanmıştır. Toplumsal cinsiyet eşitliğine yönelik eğitimlere üniversite öncesinde başlanıp üniversite eğitimi boyunca devam ettirilmesi gençlerin bu konuda bilinçlendirilmesini sağlayarak daha eşitlikçi bir bakış açısı kazanmasına katkı sağlayabilir.

$\mathrm{Bu}$ araştırmada öğrencilerin üniversite öncesi yaşadıkları yer ile toplumsal cinsiyet eşitliği ölçeği alt boyut puan ortancaları arasında anlamlı ilişki bulunmamıştır. Ancak şu an ailesiyle yaşayan öğrencilerin EÜGA ve KEBKA puan ortancalarının arkadaşları ile evde yaşayan öğrencilerden daha düşük olduğu bulunmuştur. $\mathrm{Bu}$ bulguya zıt olarak Ankara'da yapılan bir çalışmada tek başına/arkadaşları ile evde yaşayan öğrencilerin birinci derece yakınları ile ve yurtta yaşayan ögrencilerden daha eşitlikçi yaklaşım sergiledikleri bildirilmişken (10), Giresun'da yapılan çalışmada öğrencilerin kaldıkları yer (aile, özel ev, yurt) ile toplumsal cinsiyet rollerine ilişkin tutumları arasında anlamlı fark olmadığı tespit edilmiştir (16). Bu çalışmada ailesiyle yaşayan öğrencilerin daha eşitlikçi bakış açısına sahip olmaları aile ortamında gözlemledikleri eşitlikçi davranışlardan kaynaklanabilir.

Öğrencilerin Ailelerinin Tanıtıcı Özellikleri ile Toplumsal Cinsiyet Eşitliği Ölçeği Alt Boyutları Arasındaki İlişki

$\mathrm{Bu}$ araştırmada annesi okuryazar olmayan öğrencilerin annesi lise ve üzeri eğitime sahip öğrencilere göre daha fazla erkeği kadından üstün gören anlayışa sahip oldukları saptanmıştır. Ayrıca annesi okuryazar olmayan öğrencilerin annesi ilkokul ve üzeri eğitime sahip öğrencilere göre daha fazla kadını erkeğe bağımlı kılan görüşe sahip oldukları bulunmuştur. Bu bulgulara paralel olarak Zeyneloğlu'nun (10) çalışmasında anne eğitim düzeyinin yüksek olmasının öğrencilerin daha eşitlikçi düşünmeleri üzerine etkisi olduğu bildirilmiştir. Erzurum'da yapılan bir çalışmada annesi ilkokul ve lise mezunu olan öğrencilerin toplumsal cinsiyet rollerine ilişkin daha eşitlikçi tutumuna sahip oldukları bulunmuştur (7).

$\mathrm{Bu}$ çalışma bulgularına zit olarak bazı çalışmalarda babanın eğitim durumu ile öğrencilerin toplumsal cinsiyet rolleri ve tutumları arasında istatistiksel olarak anlamlı ilişki bulunmadığı belirtilmiştir $(3,4,7)$. Bu araştırma ve diğer çalışma sonuçları incelendiğinde, annenin eğitim düzeyinin çocukların toplumsal cinsiyet rollerine ilişkin eşitlikçi tutuma sahip olmalarında etkili olduğu görülmektedir. Ebeveynlerin eğitim seviyesinin artması, yeni görüşlere açık olması ve daha eşitlikçi bakış açısı ile çocuklarını yetiştirmeleri çocuklarının bu konudaki tutumlarını etkileyebilmektedir. Toplumsal Cinsiyet Rolleri Tutum Ölçeği kullanılarak Ankara'da (10), Düzce'de (3) ve İstanbul'da (4) yapılan çalışmalarda, annesi çalışan ve çalışmayan öğrencilerin toplumsal cinsiyet rollerine ilişkin puan ortalamaları arasında anlamlı bir fark bulunmamıştır. $\mathrm{Bu}$ çalışmada diğer çalışma bulgularına zıt olarak annesi çalışan öğrencilerin kadını erkeğe bağımlı kılan görüşü daha az benimsedikleri görülmektedir. Bu sonuç annenin evin dışında bir işte çalışmasının öğrencilerin toplumsal cinsiyet rollerine ilişkin görüşlerini olumlu etkilediğini göstermektedir.

$\mathrm{Bu}$ çalışmada öğrencilerin sahip oldukları kardeş sayısı ile toplumsal cinsiyet eşitliği ölçeği alt boyutları arasında istatistiksel olarak anlamlı ilişki bulunmamıştır. Hemşirelik öğrencileri ile gerçekleştirilen diğer çalışmalarda bu çalışmaya zıt olarak öğrencilerin kardeş sayısı arttıkça daha eşitlikçi tutuma sahip oldukları (10) ve kız kardeşe sahip olan öğrencilerin daha eşitlikçi bakış açısında sahip olduğu (3) belirlenmiştir. $\mathrm{Bu}$ çalışma bulgularının yapılan diğer çalışmalardan farklı çıkmasının sebebi cinsiyet rollerinin benimsenmesinde diğer faktörlerin daha etkili olması olabilir.

Öğrencilerin Toplumsal Cinsiyet Konusunda Eğitim Alma Durumu ile Toplumsal Cinsiyet Eşitliği Ölçeği Alt Boyutları Arasındaki İlişki

$\mathrm{Bu}$ çalışmada toplumsal cinsiyet kavramını duymuş, toplumsal cinsiyet konusunda eğitime katılmış ve toplumsal cinsiyet eşitliği dersini almış öğrencilerin diğer öğrencilere göre KEBKA ve EÜGA puan ortancalarının daha düşük olduğu yani daha eşitlikçi bakış açısına sahip olduğu saptanmıştır. Hemşirelik bölümü öğrencileri ile yapılan bir çalışmada toplumsal cinsiyet ile ilgili bir eğitim veya seminer almanın toplumsal cinsiyet alg1 puan ortalamalarında farklılık yaratmadığ 1 belirtilmiş olup Kadın Sağlığı ve Hastalıkları Hemşireliği dersinin öğrencilerin toplumsal cinsiyet bakış açısına etkisi incelenmiştir. Verilen dersin toplumsal cinsiyete ilişkin eşitlikçi bakış açısı bilincini kazandırdığı ve toplumsal cinsiyet algısını olumlu yönde etkilediği saptanmıştır (16).

\section{SONUÇ}

Bu çalışmada kadın, sosyal hizmet bölümünde okuyan, okur-yazar ve çalışan anneye sahip, Marmara bölgesinde doğan, en uzun süre il ve ilçede yaşamış, ailesiyle yaşayan, toplumsal cinsiyet kavramını duymuş veya bu konuda ders/eğitim almış öğrencilerin diğer öğrencilere göre KEBKA ve EÜGA puan ortancalarının daha düşük olduğu yani daha eşitlikçi bakış açısına sahip oldukları belirlenmiştir. $\mathrm{Bu}$ sonuçlar ile T.C Aile ve Sosyal Politikalar Bakanlığı (26) önerileri de göz önünde bulundurularak, toplumsal cinsiyet algısının olumlu yönde değişmesi için, sağlık personeli yetiştiren fakülte ve yüksekokulların müfredatlarında toplumsal cinsiyet eşitliği ve kadına yönelik şiddet konularının yer alması, öğrencilerin, toplumsal cinsiyet algısı ve eşitliği konusunda bilinçlendirilmesinin önemli olduğu düşünülmektedir.

Yazarların Katkıları: Fikir/Kavram: E.Y.; Tasarım: E.Y.; Veri Toplama ve/veya İşleme: Ö.T., A.B.; Analiz ve/veya Yorum: E.Y., Ö.T.; Literatür Taraması: E.Y., Ö.T., A.B.; Makale Yazımı: E.Y., Ö.T.; Eleştirel İnceleme: E.Y., Ö.T.

\section{KAYNAKLAR}

1. Öngen $B$, Aytaç $S$. Üniversite öğrencilerinin toplumsal cinsiyet rollerine ilişkin tutumları ve yaşam değerleri ilişkisi. Sosyoloji Konferansları. 2013; 48(2): 1-18. 
2. Bingöl O. Toplumsal cinsiyet olgusu ve Türkiye'de kadınlık. KMÜ Sosyal ve Ekonomik Araştırmalar Dergisi. 2014; 16(Özel Sayı I): 108-14.

3. Aydın M, Bekar EÖ, Gören ŞY, Sungur MA. Hemşirelik ögrrencilerinin toplumsal cinsiyet rollerine ilişkin tutumları. BASBED. 2016; 16(1): 223-42.

4. Kömürcü N, Yıldız H, Toker E, Karaman ÖE, Koyucu RG, Durmaz A, ve ark. Hemşirelik ve ebelik ögrencilerinin toplumsal cinsiyet rolleri ve kadına ilişkin namus anlayışları ile ilgili tutumları. JACSD. 2016; 5: 1-22.

5. García-Vega E, Rico R, Fernández P. Sex, gender roles and sexual attitudes in university students. Psicothema. 2017; 29(2): 178-83.

6. Altınova $\mathrm{HH}$, Duyan V. The validity and reliability of perception of gender scale. Toplum ve Sosyal Hizmet. 2013; 24(2): 9-22.

7. Çetinkaya SK. Üniversite öğrencilerinin şiddet eğilimlerinin ve toplumsal cinsiyet rollerine ilişkin tutumlarının incelenmesi. NPD. 2013; 1(2): 21-43.

8. Karasu F, Göllüce A, Güvenç E, Çelik S. Üniversite öğrencilerinin toplumsal cinsiyet rollerine ilişkin tutumları. SDÜ Sağlık Bilimleri Dergisi. 2017; 8(1): 21-7.

9. Akın A, Demirel S. Toplumsal cinsiyet kavramı ve sağlığa etkisi. CMJ. 2003; 25(4): 73-82.

10. Zeyneloğlu S. Ankara'da hemşirelik öğrenimi gören üniversite öğrencilerinin toplumsal cinsiyet rollerine ilişkin tutumları [Doktora Tezi]. Ankara: Hacettepe Üniversitesi Sağlık Bilimleri Enstitüsü; 2008.

11. Yılmaz DV, Zeyneloğlu S, Kocaöz S, Kısa S, Taşkın L, Eroğlu K. Views on gender roles of university students. İnsan Bilimleri Dergisi. 2009; 6(1): 775-92.

12. Alisbah Tuskan, A. Toplumsal cinsiyet toplumda kadına biçilen roller ve çözümleri. TBB. 2012; 25(99): 445-9.

13. Blau FD, Kahn LM. The gender wage gap: Extent, trends, and explanations. JEL. 2017; 55(3): 789-865.

14. Esen E, Siyez D, Soylu Y, Demirgürz G. Üniversite öğrencilerinde toplumsal cinsiyet algısının toplumsal cinsiyet rolü ve cinsiyet değişkenlerine göre incelenmesi. E-Uluslararası Eğitim Araştırmaları Dergisi. 2017; 8(1): 46-63.

15. Direk N, Irmak B. Dokuz Eylül Üniversitesi Tıp Fakültesi öğrencilerinde toplumsal cinsiyet rollerine yönelik tutumlar. Dokuz Eylül Üniversitesi Tıp Fakültesi Dergisi. 2017; 31(3): 121-8.

16. Turan Z, Aydın Y, Toker E. "Kadın Sağlığı ve Hastalıkları Hemşireliği Dersi' 'nin hemşirelik öğrencileri toplumsal cinsiyet algısına etkisinin incelenmesi. İnsan Bilimleri Dergisi. 2017; 14(3): 2677-87.

17. Düşmez İ. Çocuk gelişimi bölümü öğrencilerinin toplumsal cinsiyet rolü tutumlarının incelenmesi. JASSS. 2016; 47: 489-509.

18. Çelik AS, Pasinlioğlu T, Tan G, Koyuncu H. Üniversite öğrencilerinin cinsiyet eşitliği tutumlarının belirlenmesi. FNJN. 2013; 21(3): 181-6.

19. Buchmann C, Dalton B. Interpersonal influences and educational aspirations in 12 countries: The importance of institutional context. SOE. 2002; 75(2): 99-122.
20. Wells RS, Seifert TA, Padgett RD, Park S, Umbach PD. Why do more women than men want to earn a four-year degree? Exploring the effects of gender, social origin, and social capital on educational expectations. The Journal of Higher Education. 2011; 82(1): 1-32.

21. Gözütok FD, Toraman Ç, Acar-Erdol T. Toplumsal cinsiyet eşitliği ölçeğinin geliştirilmesi. İlköğretim Online. 2017; 16(3): 1036-48.

22. Vefikuluçay AGD, Zeyneloğlu AGS, Eroğlu K, Taşkın L. Kafkas üniversitesi son sınıf öğrencilerinin toplumsal cinsiyet rollerine ilişkin bakış açıları. Hacettepe Üniversitesi Hemşirelik Fakültesi Dergisi. 2007; 14(2): 26-38.

23. Varol ZS, Çiçeklioğlu M, Taner Ş. Bir tıp fakültesi birinci sınıf öğrencilerinde toplumsal cinsiyet alg1 düzeyi ve ilişkili faktörlerin değerlendirilmesi. Ege T1p Dergisi. 2016; 55(3): 122-8.

24. Uçtu KA, Karahan N. Sağlık yüksekokulu öğrencilerinin cinsiyet rolleri, toplumsal cinsiyet algısı ve şiddet eğilimleri arasındaki ilişkinin incelenmesi. ITOBİAD. 2016; 5(8): 2881-904.

25. Ünal F, Tarhan S, Köksal EÇ. Toplumsal cinsiyet algısını yordamada cinsiyet, sınıf, bölüm ve toplumsal cinsiyet oluşumunun rolü. BÜEFAD. 2017; 6(1): 22736.

26. sp.gov.tr [Internet]. T.C Aile ve Sosyal Politikalar Bakanlığı 2018. Kadının Güçlenmesi Strateji Belgesi ve Eylem Planı 2018-2023 [Erişim tarihi: 20.12.2018]. Erişim adresi:https://kadininstatusu.aile.gov.tr/uploads/pages/ kadinin-guclenmesi-strateji-belgesi-ve-eylem-plani2018-2023/kgsbep-2018-2023-web.pdf. 